\title{
Multi-Source Data Analyses of Processes of a Squall Line and the Gale Weather with Heavy Hails before the Squall Line
}

\author{
Meijin Huang1, Minyan Chen', Ning Pan'1, Jinqin Feng', Huiying Yue1 \\ ${ }^{1}$ Fujian Provincial Meteorological Observatory, Fuzhou, China \\ ${ }^{2}$ Longyan City Fujian Provincial Meteorological Bureau, Longyan, China \\ Email:meijin_h@126.com
}

How to cite this paper: Huang, M.J., Chen, M.Y., Pan, N., Feng, J.Q. and Yue, H.Y. (2017) Multi-Source Data Analyses of Processes of a Squall Line and the Gale Weather with Heavy Hails before the Squall Line. Journal of Geoscience and Environment Protection, 5, 27-40.

https://doi.org/10.4236/gep.2017.58004

Received: March 31, 2017

Accepted: July 24, 2017

Published: July 27, 2017

Copyright $\odot 2017$ by authors and Scientific Research Publishing Inc. This work is licensed under the Creative Commons Attribution International License (CC BY 4.0).

http://creativecommons.org/licenses/by/4.0/

\begin{abstract}
Through multi-source data analyses of regional automatic station data, wind profiling radar, lightning information, new-generation weather-radar echo data and conventional observations in Fujian Province, and others, this paper finds out aspects to focus on for potential forecasts and the nowcasting of wide-range gale weathers with thunderstorms and hail weathers in west Fujian Province on April 26th, 2016. Thus providing a basis for future forecasting of such catastrophic meteorological activities. Results of analyses showed that being affected by the eastward moving of upper troughs and the eastward and southward moving of low-level vortex shears, cold air and warm air strongly intersected in west Fujian Province; noticeable cold and warm advection formed the temperature frontal-zone; and under the triggering of the ground convergence line, impetuses formed by the strong convergent uplift before the south troughs forcibly produced wide-range squall lines, hails and other strong convective weathers. The squall line was caused by baroclinic frontogenesis. Hails with a diameter of up to $3 \mathrm{~cm}$ happened in the prefrontal warm zone. Supercells were generated and developed in the $80 \mathrm{~km}$ hot low-pressure convergence zone before the squall line moved along the direction at about $25^{\circ}$ to the right of the mean wind field of the environment, belonged to right-shifting hailstorms, were of characteristics representing the hook echo and were of characteristics that the strength of the echo was high. On the afternoon of 26th, on the ground, temperature and humidity strongly increased. Fujian was located in the warm zone in the south side of the inverted trough. The specific humidity at $850 \mathrm{hPa}$ was higher than $12 \mathrm{~g} / \mathrm{kg}$. The positive temperature change lasted for 24 hours. In the inland, the ridge was warm, while the trough was cold. Strong vertical wind shears that reached 20 $\mathrm{m} / \mathrm{s}$ at $925-500 \mathrm{hPa}$ and others were beneficial environmental conditions for
\end{abstract}


forming the process of strong convective weather of baroclinic frontogenesis for this time.

\section{Keywords}

Hailing before the Squall, Temperature Frontal-Zone, Wind Profiling Radar, Vertical Wind Shears, Supercell Storms

\section{Introduction}

Strong convective weather has characteristics that bustiness and locality are strong, the duration is short, and the disaster is severe, and so on. It is a difficulty in the weather forecasting business [1]. Since the system causing the strong convective weather belongs to medium- and small-scale weather systems and it is hard to be captured by conventional meteorological observation networks; data from automatic stations, radars, satellites, thunder and lightning, GPS, wind profiling radar and other non-conventional observation, their fused data, assimilated data and mesoscale numerical model data are main data basis for conducting short-term forecasts and nowcasting for strong convective weathers.

From 12:30 - 18:30 (Beijing time) on April 26th, 2016, a series of strong convective storms appeared. In the impact period, it brought one after another wide-range of hails, thunderstorm gale weathers and short-term heavy precipitation weathers to three cities: Nanping, Sanming and Longyan. Among them, in Yinjia Town of Jianning County and Datian Town of Taining County, heavy hails of more than $2 \mathrm{~cm}$ appeared at 13:20; in Jiangle, Changting, Liancheng and other places, the hail weather also appeared. There were already 52 automatic stations where the gale reached higher than force eight on the Beaufort scale. The maximum 1-hour rain intensity was $53.6 \mathrm{~mm} / \mathrm{h}$ appeared on the top of the Guangze Mountain. One supercell at $80 \mathrm{~km}$ front of the squall line caused a severe disaster. This storm lasted for about $2.5 \mathrm{~h}$ (for Pucheng and Songxi among them, the affecting time was about $1 \mathrm{~h}$ ). From the south side of the radar station, it moved about $100 \mathrm{~km}$ in the northeast direction (Figure 1). At around 14:00, in Shuibeijie Town of Pucheng, a hurricane of $54.9 \mathrm{~m} / \mathrm{s}$ (force sixteen on the Beaufort scale) appeared, being the highest record of onshore gales in Fujian [2]. From around 14:00 to around 14:30, hails of the size of a chicken egg appeared in multiple places such as Pucheng and Songxi, and the maximum hail diameter reached $3 \mathrm{~cm}$. The process of this strong convective weather made civil houses collapse, affected crops and tobaccos, made roads collapse, and damaged water conservancy and power facilities; the direct economic loss exceeded CNY 100 million.

This article will use multi-source data to analyze the causes of the strong convective weather on April 26th, 2016, attach importance to the analyses for environmental field conditions of the mesoscale convective weather, structures of supercells and their evolutionary characteristics in the process of this time with a view to providing aspects to focus on for further analyzing the potential of this 


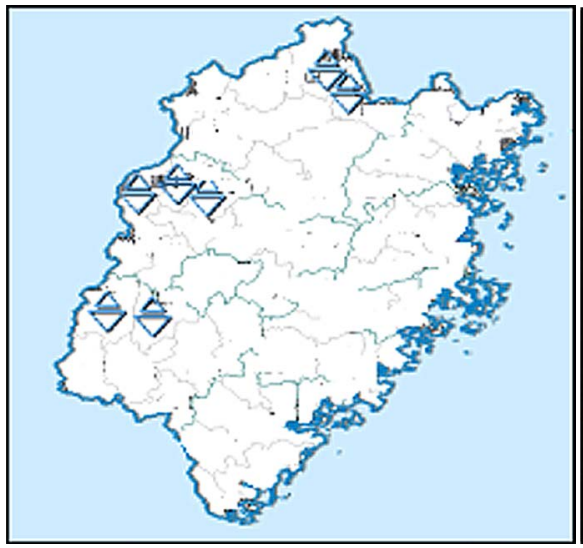

(a)

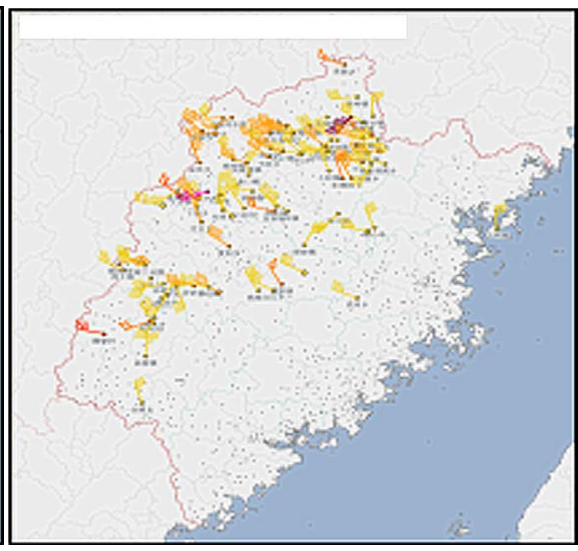

(b)

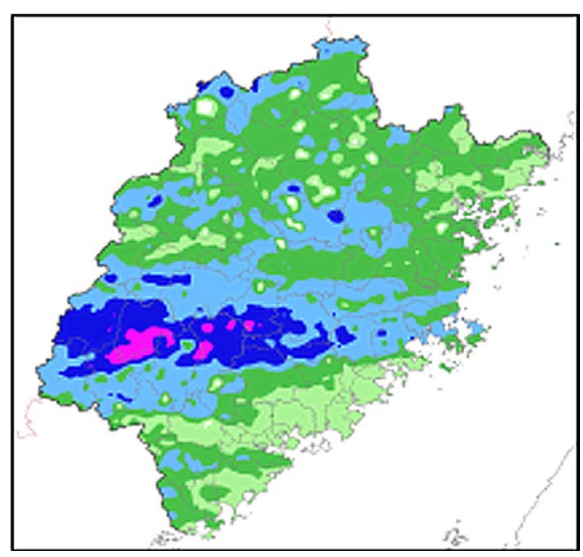

(c)

Figure 1. 8:00 at April 26 to 8:00 at April 27: (a) Hail live, (b) Strong winds above level 8, and (c) 24 hours cumulative precipitation.

type of strong convective weather [3] of baroclinic frontogenesis and for the nowcasting in the future, so as to provide a forecast for further analysis of the potential and near-forecast of such baroclinic strong convective weather in the future. Thus to establish the basis for the future accurate prediction of this severe convective weather, minimizing the losses caused by the disaster.

\section{Environmental Field Conditions of Strong Convective Weathers}

The process of the strong convective weather of this time was a process of the eastward moving of upper troughs, and the eastward and southward moving of vortex shears. At 8:00 a.m. on April 26th, 2016, at $500 \mathrm{hPa}$ in the medium and high latitudes, it was one-ridge one-trough type. Medium- and high-latitude circulations were flat and straight with multiple small fluctuations. At 8:00 a.m., in the east of the plateau, there were troughs that moved eastward. South fluctuations of the medium and the low latitudes were developing. Between the south trough and the subtropical high pressure belt, there was a southwest wind jet of $\geq$ $20 \mathrm{~m} / \mathrm{s}$. The center of the jet was in Ganzhou, reached $24 \mathrm{~m} / \mathrm{s}$. North Fujian Province was in the warm and humid southwest airflow before the trough. At 
$850 \mathrm{hPa}$, in the range of Anhui, there was a vortex center of 148. In the zone including Nanning, Wuzhou, Ganzhou, Shaowu and other places in the south side of the shear, there was a low-altitude southwest wind jet of $\geq 12 \mathrm{~m} / \mathrm{s}$; the center of the jet was in Wuzhou and reached $18 \mathrm{~m} / \mathrm{s}$. West Fujian Province was in the south side of the vortex shear and in front of the southwest jet axis, with obvious wind-speed convergence. The zone of $850 \mathrm{hPa}$ in west Fujian Province was in the wet zone with a specific humidity of more than $12 \mathrm{~g} / \mathrm{kg}$. Regarding the precipitable water of the whole layer, it was more than $4 \mathrm{~cm}$ at 8:00 a.m. across west Fujian. The zone of $500 \mathrm{hPa}$ was a dry zone with a T-Td $15^{\circ} \mathrm{C}$; it was stacked with a state that the upper was dry and the lower was wet. The low-layer southwest jet of west Fujian Province transported warm wet advection. The ground was in the warm zone of the cold prefrontal inverted trough. For 24 hours, at the zone of $850 \mathrm{hPa}$, there was a positive temperature change. Since the development of the warm ridge, and there were warm ridges and cold troughs in the west; the T85 was higher than $25^{\circ} \mathrm{C}$, the instability increased, the cold advection and the warm advection caused baroclinic frontogenesis (Figure 2). At 14:00, the vortex shear

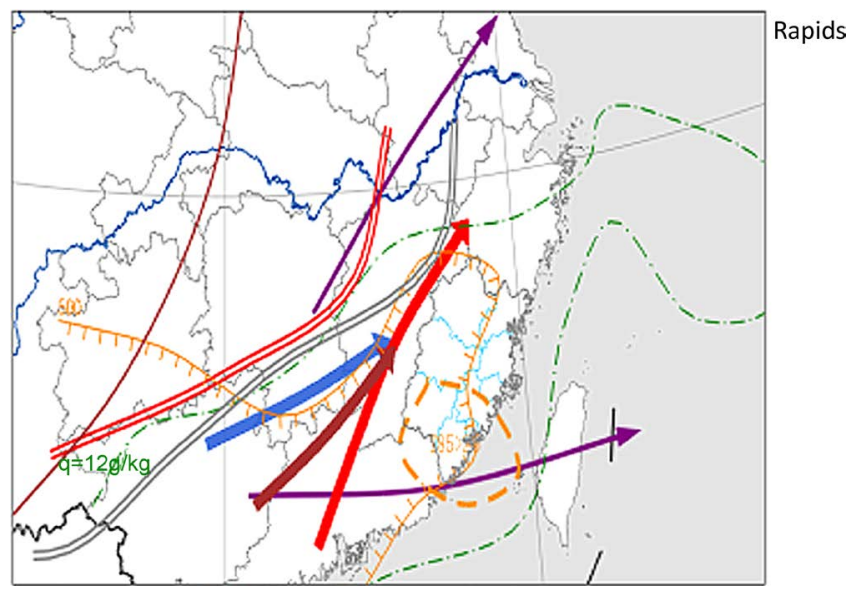

(a)

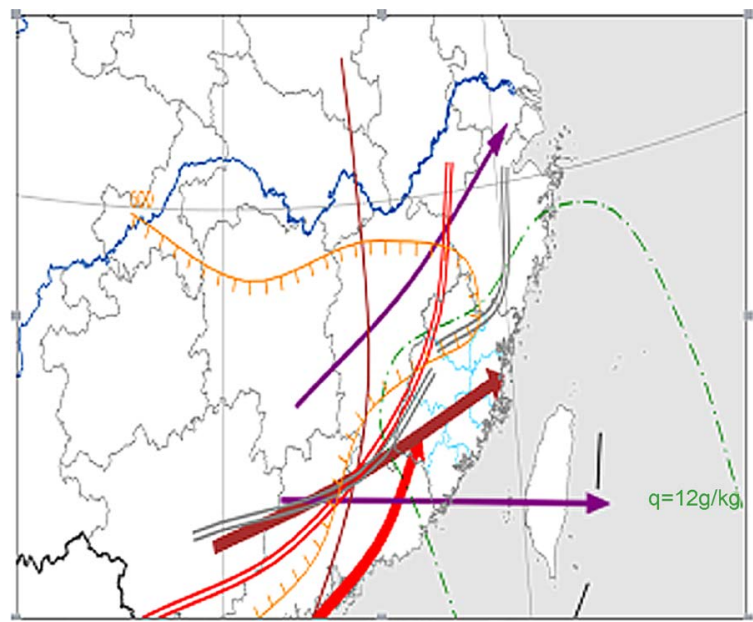

(b)

Figure 2. Analysis of meso-scale weather environment fields at (a) 08:00 and (b) 20:00 on April 26th. 
and the jet axis moved eastward and southward. In the ground, there was an obvious frontal-zone moving southward. The convergent uplift before the south trough of the low-layer shear provided good dynamic uplift conditions for the process of this time. In the process of this time, cold air and warm air strongly intersected in west Fujian Province. Noticeable cold and warm advections formed the temperature frontal-zone; under the triggering of the ground convergence line, impetuses formed by the strong convergent uplift before the south trough forcibly produced wide-range squall lines, hailing and other strong convective weathers. The squall line was caused by baroclinic frontogenesis; and formed, developed and became supercells in the low-pressure hot convergence zone at $80 \mathrm{~km}$ in front of the squall line.

\section{Environmental Parameters of Thunderstorm Gales and Radar-Parameter Characteristics}

\subsection{Parameter Characteristics of the Convective Environment of Thunderstorm Gales [4]}

The radial degree at $500 \mathrm{hPa}$ was big. In front of the low trough (with a latitude of higher than $10^{\circ}$ ), there were negative pressure changes of lower than -3 dagpm. Bigger advections with positive vorticities before the trough resulted in the development of low-layer low-pressure systems [5], and the squall line appeared. The squall line and the isolated supercell storm in front of the squall line directly resulted in gale and hail weathers that led to disasters. Low troughs of high radial degrees, the interaction between three layers of southwest jet systems of which the boundary layers reached $500 \mathrm{hPa}$, the temperature frontal-zone on the ground, mesoscale convergence lines, meso- $\gamma$-scale warm low pressures, strong-wind vertical shears and others were beneficial conditions for the development of squall lines and supercells of storms.

At 8:00, at $850 \mathrm{hPa}$ from Guangxi and central Guangdong to central north Jiangxi, warm wet southwest jets that were strong prevailing were established and spread eastward. The angle between the direction of wind and the isotherm line was big. Warm advection was noticeable. From south China to central north Jiangxi, there were low-layer warm ridges. At $500 \mathrm{hPa}$ in the zone from north Fujian to Zhejiang, there were negative temperature changes. Moreover, at 700 $\mathrm{hPa}$, there were low troughs that moved eastward. In the medium and low layers of the north, it was accompanied by more obvious cold advections. Cold and warm advections intersected in west Fujian Province. Warm ridges and cold troughs were beneficial to the establishment of instable stacks. In the afternoon, in northwest Fujian, the T85 rose to $25^{\circ} \mathrm{C}-26^{\circ} \mathrm{C}$. For se $85<-10^{\circ} \mathrm{C}$, an instable zone in the direction of northeast-southwest existed in the zone from the north of south China to west Fujian Province. The T75 vertical temperature difference was higher than $16^{\circ} \mathrm{C}$. The CAPE in the inland of Fujian reached $2364 \mathrm{~J} / \mathrm{Kg}$, and the DCAPE exceeded $500 \mathrm{~J} / \mathrm{kg}$. The instability of convection was beneficial to the generation of thunderstorm gales. 
After analyzing the encrypted ground-meteorological-automatic-station-data (Figure 3) during the daytime on 26th in Fujian, it was seen that the temperature and the humidity of the ground in the afternoon strongly increased. In central Sanming and most of Nanping, warm centers with temperatures approaching $31^{\circ} \mathrm{C}$ appeared. The increase in the temperature of the ground made the ground air pressure decrease. In the warm zone, mesoscale hot-low-pressures formed. The development of the ground inverted trough was obvious. And a ground frontal-zone in the direction of northeast-southwest could be worked out after analyses. The temperature gradient was high. The temperature difference reached $9^{\circ} \mathrm{C} / 100 \mathrm{~km}$, and it was accompanied by ground convergence lines. The mesoscale temperature frontal-zone enhanced the baroclinicity of the atmosphere. Convective cells that moved from Jiangxi to Nanping, Sanming and Longyan District rapidly developed under the uplift effect of the convergence line and

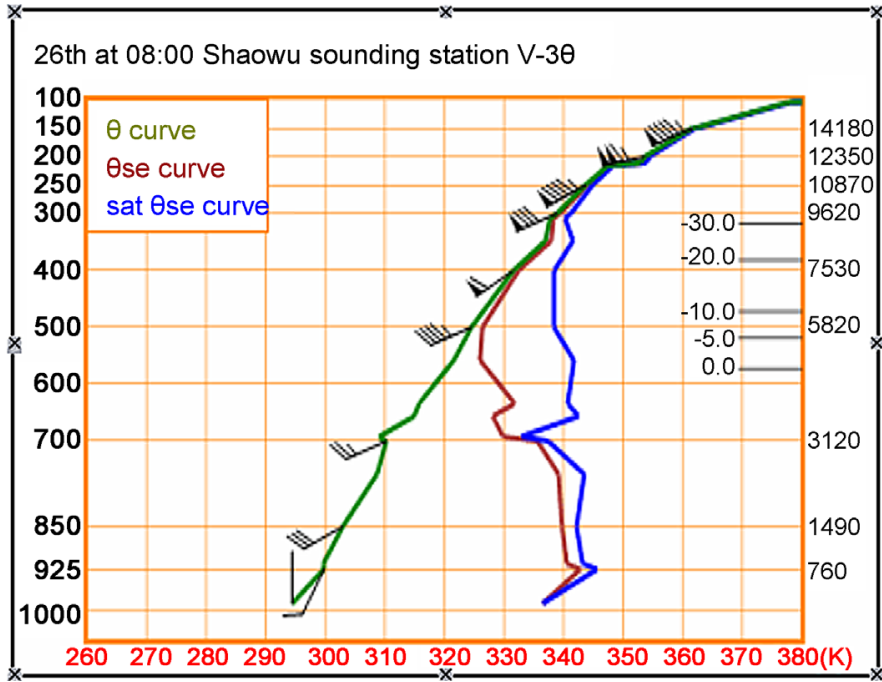

(a)

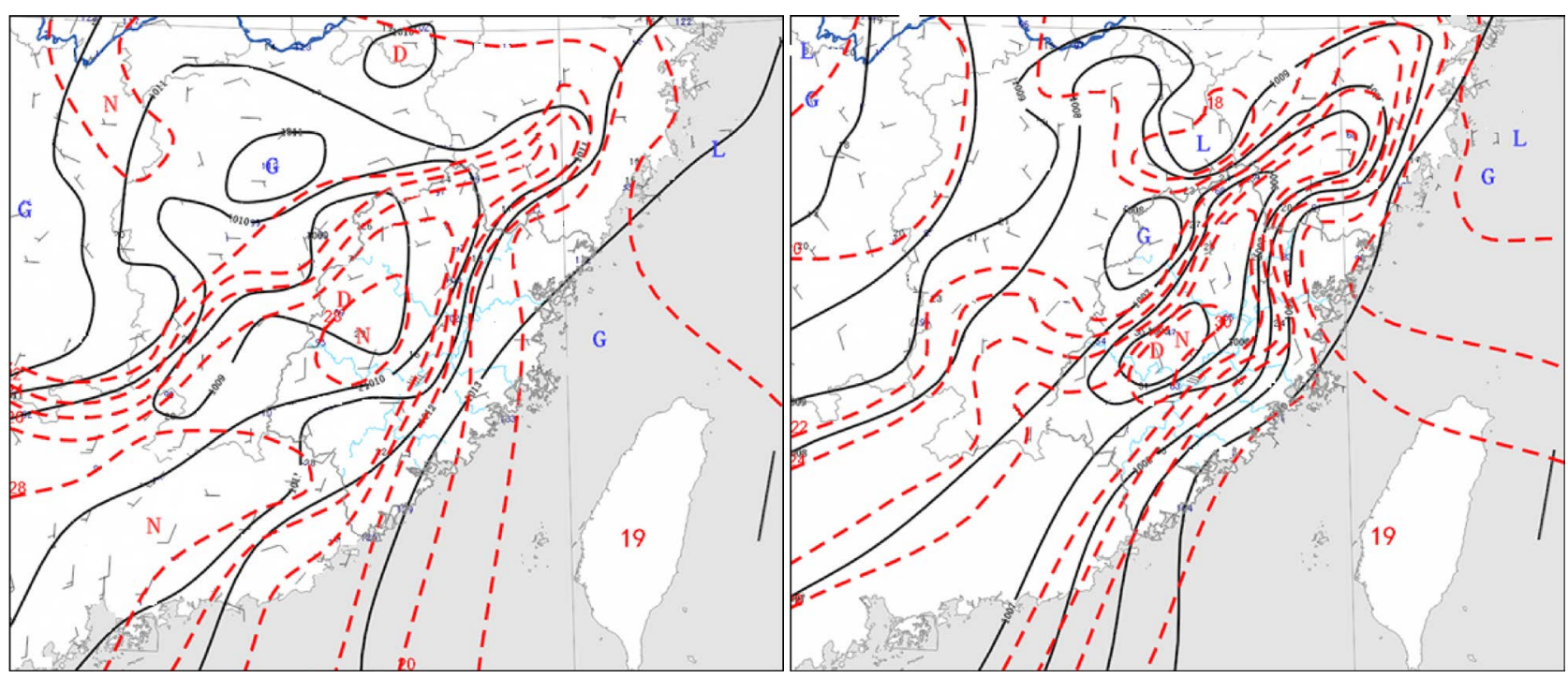

(b)

(c)

Figure 3. (a) 26th at 08:00 Shaowu sounding station V-3 $\theta$, (b) 11:00 and (c) 14:00 ground data encryption analysis. 
rapidly moved in the northeast direction along the front. The ground temperature frontal-zone and the mesoscale convergence line played an important role in triggering and maintaining the squall line system. The squall line produced wide-range thunderstorm gale weathers. In Nanping District, the maximum record for onshore gales in Fujian appeared.

Along with the eastward moving of the shear and the east spread of the southwest jet, adequate water vapor was transported to occurrence areas of the strong convections. Warm ridges and moist tongues formed. At 8:00 a.m. on 26th, the temperature-dew point difference at $850 \mathrm{hPa}$ was lower than $2^{\circ} \mathrm{C}$; the dew point was $15^{\circ} \mathrm{C}-16^{\circ} \mathrm{C}$; specific humidity fields of more than $14 \mathrm{~g} / \mathrm{kg}$ distributed in the region of south China in the shape of tongue. Low layers were in the high-humidity environment. The precipitable water of the whole layer at 8:00 a.m. reached $30 \mathrm{~mm}$, and then rose to $45 \mathrm{~mm}$. The zone at $500 \mathrm{hPa}$ of the west of our province was a dry zone of which the temperature-dew point difference was higher than $15^{\circ} \mathrm{C}$. In the sky over the instable zone, the temperature and humidity profile had obvious characteristics that "the upper was dry, while the lower was wet". In the medium layer of the convection layer, obvious dry layers existed, and it was beneficial to the generation of the thunderstorm gale.

From analyses of radiosonde data, at 8:00 a.m. on 26th, in Shaowu, inversion layers at $956 \mathrm{hPa}$ appeared. Formed dry warm lids were beneficial to the accumulation of a lot of energy. Moreover, the lifting condensation level (LCL) was low and lower than $950 \mathrm{hPa}$; it indicated that in the afternoon, under the uplift effect of external forces, it was very easy for the air parcel to uplift and reached saturation. Moreover, the strong vertical wind shear of which the wind vector difference between the ground and the $500 \mathrm{hPa}$ zone was higher than $20 \mathrm{~m} / \mathrm{s}$ reached the value of ambient wind shear for supercells and even squall lines and hailstorms. The direction of wind in the low layers veered along with the change of height; it was beneficial to the right-handed rotation of cells of hailstorms.

From analyses of lightning information, negative ground lightning mainly happened in the convection zone in the front of the squall line, while most of positive ground lightning appeared in the stratiform region in the rear of the squall line. Dense negative ground lightning was corresponding to the updraft in the cloud. The higher frequency the negative ground lightning had, the more flourishing the development of mesoscale convection systems was. In the core of the updraft, it was negative charge region $(7 \mathrm{~km})$ that the hail carried, and it was beneficial to the generation of the strong convective weather. Along with the development of the squall line, the frequency of the positive ground lightning also started to increase. Since positive charge centers mainly located at $5 \mathrm{~km}$ and 10 $\mathrm{km}$, ramped airflows formed by wind shears made the positive charge region of high-layer cloud ice and the medium-layer negative charge regions incline and form the cloud anvil, decreased the shielding effect of negative charges. In the front of the squall line, the amount of positive ground lightning also increased correspondingly. 


\subsection{Radar-Parameter Characteristics of Thunderstorm Gales}

At around 12:30, the appearance of the rear inflow notch of the reflectivity factor in the Figure 4 indicated that the bow echo was about to form. At 13:00, in the direction of southwest, the banded echo-squall line with a length approaching $350 \mathrm{~km}$ happened in front of the upper trough in the west wind belt, consisting of multi-cell storms and supercell storms. The squall line moved $400 \mathrm{~km}$ in $6 \mathrm{~h}$, with an average speed of movement of up to $65 \mathrm{~km} / \mathrm{h}$. Elements of meteorological stations in regions that were passed by changed severely. The temperature was lowered by $3^{\circ} \mathrm{C}-5^{\circ} \mathrm{C}$, and the air pressure was enhanced by $1-3 \mathrm{hPa}$. In most of the inland region, gales of force higher than eight on the Beaufort scale appeared. Since the vertical shear type of wind, the south end of the squall line was beneficial to the new development of the convection, and made the squall line continually elongate. And at the north end of the squall line, old cells gradually declined, evolved into stratiform clouds, expanded in the direction of northeast along the direction of high-altitude wind and formed large anvil clouds, i.e. anvil-like clouds, stretching in front of the squall line. And in rear of the squall line, precipitation areas of stratiform clouds were not so obvious (Figure 4). In the Figure 4 of the radial velocity, corresponding to the gradient region of the strong reflectivity factor of the front edge of the squall line, on the bow top of the lower layer, several characteristics of small-scale cyclonic-vortex

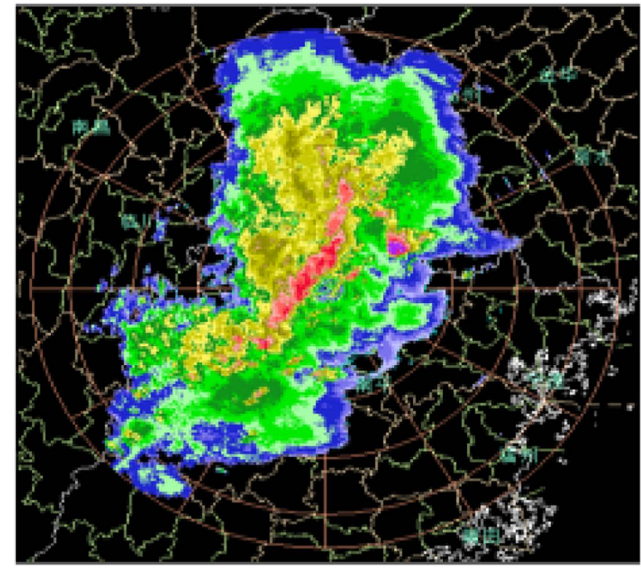

(a)

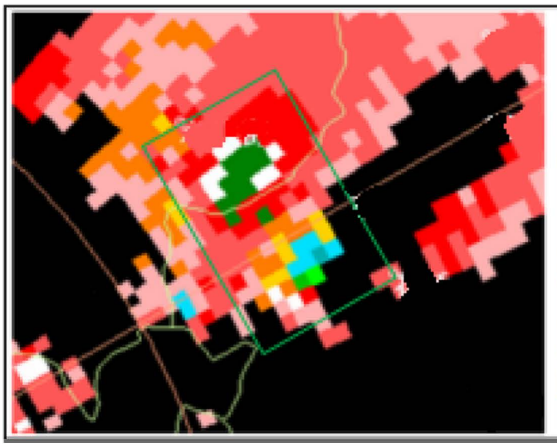

(c)

(d)

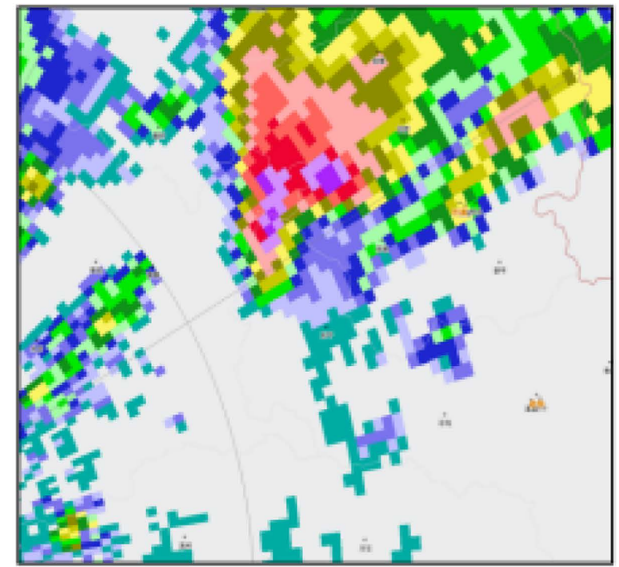

(b)

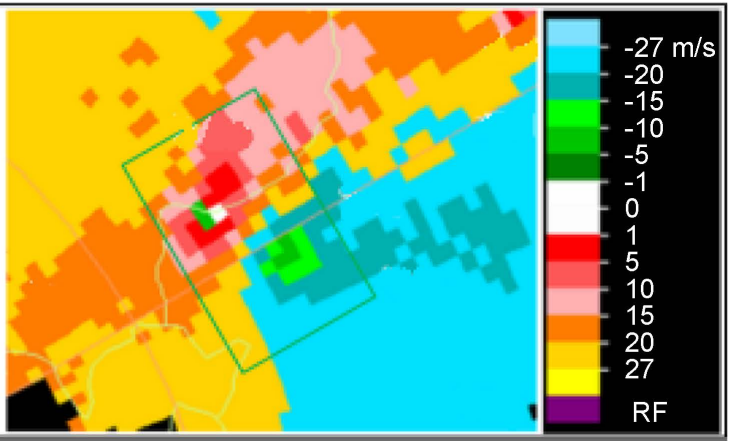

Figure 4. 26th 14:03: (a) CR37, (b) R1.5 ${ }^{\circ}$, and 26th 13:57: (c) V271.5 ${ }^{\circ}$, and (d) V276.0 Jianyang radar products. 
velocity appeared. The front edge of the bow echo continually produced mesocyclones. The front edge of the echo area was corresponding to the gale area (cooperated with the southwest jet in the front side of the shear). In the radial velocity field at the elevation angle of $1.5^{\circ}$, obvious characteristics of rear-inflows and anterior convergence appeared. From $3-7 \mathrm{~km}$, an obvious mid-altitude radial convergence (MARC) existed [6]. The maximum difference between the positive velocity and the negative velocity was $34 \mathrm{~m} / \mathrm{s}$. In the low layer in the rear side of the squall line, there was a wind speed area toward the radar; its size was about $40 \mathrm{~km}$; it was of higher than $-27 \mathrm{~m} / \mathrm{s}$ in a wide range. This indicated the existence of medium- and low-altitude strong rear-inflow jets. In places that this bow storm passed by, short-term gales together with short-term heavy precipitations appeared.

The strong echo area was corresponding to the convergence zone and the zero-velocity break angle. After the strong echo area passed by the radar station, from wind-profile products, it could be seen that the direction of wind in the radar station changed from southwest to northerly, namely, there was correspondingly processes in which shears moved eastward and southward. When the echo of the squall line moved outside Sanming and Nanping and entered eastern coasts of Fujian, since the moving speed of the squall line was too rapid, it was far away from the main system and the cooperation of the environmental field was lacking; the precipitation of the wide-range stratiform clouds in front of the squall line consumed a lot of energy, the high coastal temperature was lower than $27^{\circ} \mathrm{C}$, conditions of energy and impetus were weakened, the strength of the convection system was weaken and the convection system rapidly moved eastward to the sea.

\section{Environmental Parameter Characteristics and Radar Parameter Characteristics of Hail}

\subsection{Characteristics of Convective-Environment Parameters for Hail}

At 8:00 a.m. on 26th, the ground southwest inverted trough developed, and Fujian was in the warm zone in the south side of the inverted trough. In the afternoon, the air temperature on the ground had already obviously increased. In central Sanming and most of Nanping, warm centers of which air temperatures approaching $31^{\circ} \mathrm{C}$ appeared. The temperature of the ground increased, and it made the ground air pressure decrease. In the warm zone, mesoscale hot low pressures formed. The front edge of the cold pool formed by the converging of outflows of the strong downdraft in the thunderstorm group that made up the squall line and the hot low-pressure convergence zone at about $80 \mathrm{~km}$ in front of the bow echo interacted with each other. And the interaction triggered the generation of supercells.

In the horizontal wind field (Figure 5) of the wind profiling radar, it could also be seen that before the occurrence of the strong convection, the medium- 


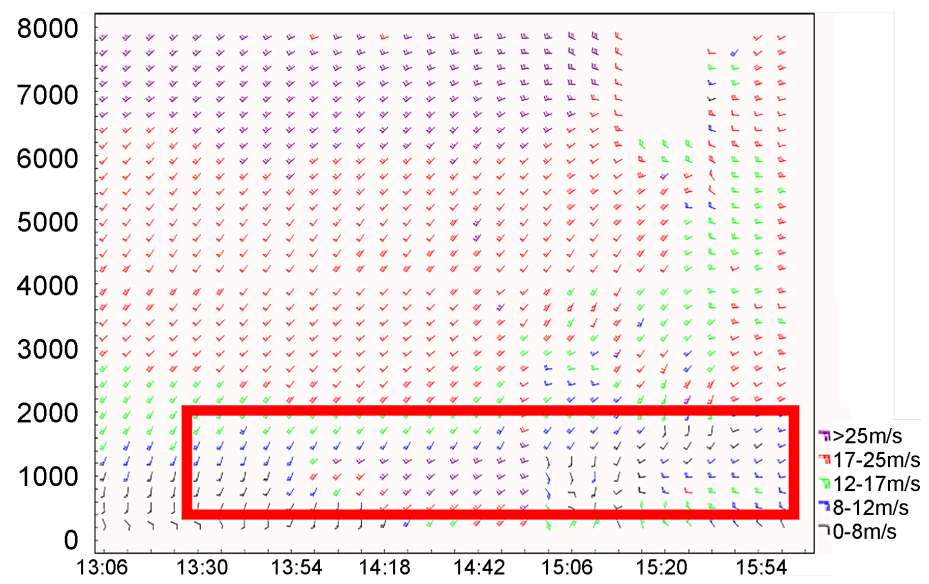

(a)

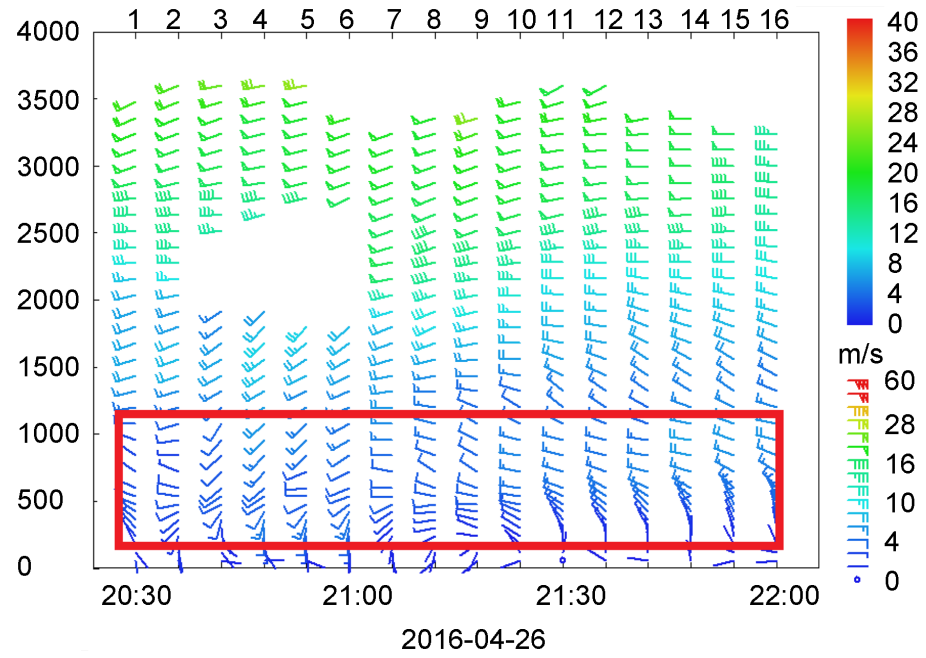

(b)

Figure 5. 26th 13:06 - 16:06 Jianou (a) and 20: 30 - 22: 00 Yong'an (b) wind profile radar products.

and low-altitude southwest jet was strong. When the height was $2 \mathrm{~km}$, it reached $20 \mathrm{~m} / \mathrm{s}$. Below $1.5 \mathrm{~km}$, it reached $12 \mathrm{~m} / \mathrm{s}$. Moreover, from $5 \mathrm{~km}-6 \mathrm{~km}$, the southwest wind was gradually strengthened, with the maximum at up to $32 \mathrm{~m} / \mathrm{s}$. During the occurrence and the passing of the strong convection, phenomenon that data were lacking, i.e. the "gap" area appeared. In the low layer, the process of the rotation of the wind direction appeared. It indicated that there were ground cyclone effects. Moreover, the height at which the vertical velocity in the period of thunderstorm gales was higher than $4 \mathrm{~m} / \mathrm{s}$ reached $5000 \mathrm{~m}$ to $6000 \mathrm{~m}$.

At 8:00 on 26th, in the radiosonde station V-3 $\theta$ (Figure 3) in Shaowu, it exhibited that in high layers, there were obtuse break angles and ultra-low temperatures; in medium and low layers, there were clockwise tumbles, three-line inflexions, cold-layer clouds appeared at $700 \mathrm{hPa}$, the fact that the upper was dry and the lower was wet (wet layers reached $700 \mathrm{hPa}$ ), bee's waist-like structures and other characteristics beneficial to hailing. The radiosonde structure in Shaowu that hail gales happened showed that the upper was dry, the lower was 
wet, heights of the $0^{\circ} \mathrm{C}$ layer and the $-20^{\circ} \mathrm{C}$ layer were $4470 \mathrm{~m}$ and $7808.7 \mathrm{~m}$, respectively, heights of the $0^{\circ} \mathrm{C}$ layer and the $-20^{\circ} \mathrm{C}$ layer were moderate, vertical wind shears were high, before the occurrence of hailing, the phenomenon that the GPSMET suddenly increased appeared; and it was beneficial to the occurrence of hailing weathers.

\subsection{Radar Parameter Characteristics of Hail}

In the low layer of the atmosphere, the wind direction rotated in a clockwise direction along with the change of the height. The velocity of the wind increased. Especially between the ground and the $850 \mathrm{hPa}$ zone, the clockwise rotation amplitude of the wind was the highest. It was beneficial to the generation of supercell storms that were cyclonically moving in the right-handed direction.

The hail-cloud echo at about $80 \mathrm{~km}$ in front of the echo area of the squall line was in the ground warm zone, was developed from the convection cell near Jianyangjuchou at 12:04 p.m., mainly was affected by guide airflows, and moved in the northeast direction. The affecting time of hail-cloud cells was about $2.5 \mathrm{~h}$ of which time to cause hailing in the zone of south Pucheng and north Songxi was about $1 \mathrm{~h}$. This isolated convective supercell made hail gales and other strong convective weathers appear in Shuibeijie Town of Pucheng County and four towns in Songxi County: Zudun, Huaqiao, Weitian and Jiuxian. After the hail clouds developed and became mature, the "right-handed rotation" appeared in the moving-out path.

In the period when hails appeared, in the Figure 5 of the reflectivity factor of the radar in Jianyang, strong-echo area in which the strength of echo was higher than $65 \mathrm{dBz}$ exhibited an "elliptical" shape. Furthermore, from all the three elevation angles in the low layers, it could be seen that the reflectivity gradient in the right side of the cell was very high. In the low layer, the cell echo exhibited a hook shape, indicating that there were strong air inflows. At 14:21 p.m. the sidelobe echo appeared. Having a look at the reflectivity Figure 5 of the radar in Wenzhou, could find that this convective cell exhibited a three-body scattering phenomenon, indicating that big hails existed. From the Figure 5 of the radial velocity, it could be seen that the mesocyclone existed corresponding to strong echoes. Moreover, the velocity of the mesocyclone was very high. The velocity blur had already appeared. From the yellow $27 \mathrm{~m} / \mathrm{s}$ region (in the green box of Figure 4) of the maximum value in the positive velocity region, two color blocks appeared, i.e. the green $(-15 \mathrm{~m} / \mathrm{s})$ and the red $(1 \mathrm{~m} / \mathrm{s})$, separately, indicating that the velocity blur existed. Among them, the velocity of the green block should range from $39-44 \mathrm{~m} / \mathrm{s}$. The actual velocity value of the red block ranged between $54 \mathrm{~m} / \mathrm{s}$ and $59 \mathrm{~m} / \mathrm{s}$. Therefore, the height of this strong echo from the ground was about $1.1 \mathrm{~km}$. Therefore, regarding the wind velocity at this time, the height from the ground was high; when it was approaching the ground, because of the friction effect, the wind velocity should be somewhat lower; this was also very close to the fact that the velocity of the monitored hurricane in Shuibei 
Village of Pucheng reached $54.9 \mathrm{~m} / \mathrm{s}$. So it indicated that the hurricane of force 16 on the Beaufort scale monitored in Shuibei Village was of credibility. Moreover, the hook echo and the mesocyclone already indicated that this cell had already developed and become a supercell [7]. The height of the strong echo centroid of higher than $65 \mathrm{dBz}$ reached $8.2 \mathrm{~km}$. The vertical profile also exhibited obvious bounded weak-echo-regions and overhanging structures. For the supercell, from 14:09 p.m. to 14:15 p.m., the VIL value of the echo jumped rapidly from $52 \mathrm{~kg} / \mathrm{m}^{2}$ to $60 \mathrm{~kg} / \mathrm{m}^{2}$. When the cell entered Songxi at 14:27 p.m., the VIL value was still $61 \mathrm{~kg} / \mathrm{m}^{2}$; subsequently, it rapidly decreased, indicating that railing appeared. This was also very consistent with the actual condition that hails of the size of a chicken egg appeared at around 14:30 p.m. in multiple places in Songxi: Zudun, Huaqiao, Weitian and Jiuxian.

\section{Concluding Remarks}

1) The process of the strong convective weather of this time moved eastward in the low trough of high radial degree. The low-level vortex shear moved eastward and southward. It resulted from effects of main systems such as the interaction between the three layers of southwest jet systems of which the boundary layer reached $500 \mathrm{hPa}$, the southward moving of the ground cold front and others. The cold air and the warm air strongly intersected in west Fujian Province. Noticeable cold and warm advections formed the temperature frontal-zone with a temperature difference reached $9^{\circ} \mathrm{C} / 100 \mathrm{~km}$ and the impetus formed by the strong convergent uplift in front of the south trough under the triggering of the ground mesoscale convergence line forcibly produced wide-range squall lines, hails and other strong convective weathers. The squall line was caused by baroclinic frontogenesis, was generated, developed and became supercells in the meso- $\gamma$-scale hot low-pressure convergence zone at $80 \mathrm{~km}$ in front of the squall line.

2) From analyses of environmental parameter characteristics of thunderstorm gales, it was worked out that the warm ridge and the cold trough were beneficial to the establishment of instable stacks. In the afternoon, in northwest Fujian, the T85 rose to $25^{\circ} \mathrm{C}-26^{\circ} \mathrm{C}$. For se $85<-10^{\circ} \mathrm{C}$, an instable zone in the direction of northeast-southwest existed in the zone from the north of south China to west Fujian Province. The T75 vertical temperature difference was higher than $16^{\circ} \mathrm{C}$. The medium layer was a dry zone and the DCAPE exceeded $500 \mathrm{~J} / \mathrm{kg}$. Strong vertical wind shears of greater than $20 \mathrm{~m} / \mathrm{s}$ and others were beneficial to the generation of thunderstorm gales.

3) From analyses of radar parameter characteristics of thunderstorm gales, it could be seen that in the inflow side of the bow echo, a gradient region of high reflectivity factors existed. The front edge of the bow echo continually produced mesocyclone. In the rear side of the bow echo, a strong down rear inflow jet of -27 $\mathrm{m} / \mathrm{s}$ existed. The mid-altitude radial convergence (MARC) between $3 \mathrm{~km}$ and 7 $\mathrm{km}$ could be used for the early warning of extreme ground gales. Moreover, the 
detection of the deep, thick, long dryline convergence zone (DCZ) in the supercell in front of the squall line also could produce extreme ground hurricanes of force 16 on the Beaufort scale.

4) From analyses of environmental parameter characteristics of hails, it was worked out that in the low layer in the inland of Fujian, the specific humidity reached more than $14 \mathrm{~g} / \mathrm{kg}$, the CAPE was higher than $2000 \mathrm{~J} / \mathrm{Kg}$, heights for $0^{\circ} \mathrm{C}$ and $-20^{\circ} \mathrm{C}$ were suitable, there were strong vertical wind shears and other beneficial environmental conditions for hailing, V-3 $\theta$ exhibited high-layer obtuse break angles and ultra-low temperatures, there were clockwise tumbles in medium and low layers, there were three-line inflexions, cold-layer clouds appeared at $700 \mathrm{hPa}$, there were bee's waist-like structures and other characteristics beneficial to hailing.

5) The supercell moved with a deviation to the right side by about $25^{\circ}$ along the mean wind field of the environment. The direction of wind in the low layers over the radiosonde veered along with the change of height; it was beneficial to the generation of right-shifting hailstorms. The height of the strong echo centroid is higher than $65 \mathrm{dBz}$ each $8.2 \mathrm{~km}$. The vertical profile also had obvious bounded weak-echo-regions, strong air inflows and the VIL value of up to 61 $\mathrm{kg} / \mathrm{m}^{2}$. This was also very consistent with the actual condition that hails of the size of a chicken egg appeared at around 14:30 p.m. in multiple places in Songxi: Zudun, Huaqiao, Weitian and Jiuxian. In the low layer, the echo exhibited a hook shape, the mesocyclone existed corresponding to strong echoes. And the velocity of the mesocyclone was very high, ranged between $54 \mathrm{~m} / \mathrm{s}$ and $59 \mathrm{~m} / \mathrm{s}$. This was also very close to the fact that the velocity of the monitored hurricane in Shuibei Village of Pucheng reached $54.9 \mathrm{~m} / \mathrm{s}$. It indicated that the hurricane of force 16 on the Beaufort scale monitored in Shuibei Village was of credibility.

\section{Acknowledgements}

The study was funded by the Fujian Provincial Open Research Fund Project (2016K01).

\section{References}

[1] Zheng, Y.G., Zhang, X.L. and Zhou, Q.L. (2010) The Progress and Challenges of Short-Term Nearly Forecasting Business Technology. Meteorological, 36, 33-42.

[2] Liu, A.M. (1999) Analysis and Forecast of Main Disastrous Weather in Fujian Province. Training Bureau of Fujian Meteorological Bureau.

[3] Xu, A.H., Sun, J.S. and Xu, D.P. (2014) The Weather Situation Classification and Basic Element Distribution Characteristics of Strong Convective Weather in Middle and East China. Meteorological, 40, 400-411.http://dx.doi.org/10.1109/9.402235

[4] Liao, X.N. (2009) Analysis on the Environmental Characteristics of Beijing Thunderstorm. Climate and Environment Studies, 14, 54-62.

[5] Sun, J.S., Dai, J.H. and He, L.F. (2014) The Basic Principle and Technical Method of Strong Convective Weather Forecast. Meteorological Press, Beijing, 203-204.

[6] Xu, X.D., Yao, Q.P. and Xiong, T.N. (2006) Principle and Business Application of 
Doppler Weather Radar. Meteorological Press, Beijing, 90-155, 163-201.

[7] Zheng, Y.Y., Yu, X.D. and Fang, C. (2004) Analysis of Doppler Weather Radar Observation Data of a Typical Super Monomer Storm. Journal of Meteorology, Beijing, $62,317-328$.

Submit or recommend next manuscript to SCIRP and we will provide best service for you:

Accepting pre-submission inquiries through Email, Facebook, LinkedIn, Twitter, etc. A wide selection of journals (inclusive of 9 subjects, more than 200 journals)

Providing 24-hour high-quality service

User-friendly online submission system

Fair and swift peer-review system

Efficient typesetting and proofreading procedure

Display of the result of downloads and visits, as well as the number of cited articles Maximum dissemination of your research work

Submit your manuscript at: http://papersubmission.scirp.org/

Or contact gep@scirp.org 